\title{
Effect of Solvent Polarity on Extraction Yield of Total Flavonoids with Special Emphasis to Glabridin from Glycyrrhiza glabra Roots
}

\author{
Sadanand YEWALE* (D), Zeba FARASH ${ }^{* *}$ (D), Shrikant KULKARNI ${ }^{* *}$ (D), \\ Shital PALGHADMAL ${ }^{* * * *}$ (D), Neelam ATHAWALE ${ }^{* * * *}$ (D), Laxman SAWANT ${ }^{* * * * * *}$ (D), \\ Shrinivas BHOPE ${ }^{* * * * * * *}$ (D), Sriram PADMANABHAN ${ }^{* * * * * * * *}$ (D)
}

Effect of Solvent Polarity on Extraction Yield of Total Flavonoids with Special Emphasis to Glabridin from Glycyrrhiza glabra Roots

\section{SUMMARY}

Different organic solvents (ethanol, dichloromethane, ethyl acetate and acetone) were studied for their effects on the extraction efficiency of glabridin and total flavonoids (TF) from Glycyrrhiza glabra roots. The extract yield of Glycyrrhiza glabra roots was in the range of 3\% to $6 \%$ following the extraction efficiency in the order ethanol $>$ acetone $>$ ethyl acetate $>$ dichloromethane. A higher extraction yield of TF and glabridin was obtained with dichloromethane, followed by ethyl acetate, acetone and ethanol, indicating that the non-polar solvents help in optimal extraction of TF and glabridin. We also demonstrate for the first time, that the extraction efficiency of the flavonoids is not significantly affected by the use of the recovered solvents except in case of ethanol which reflects that the moistureabsorbing capacity of the solvent dictates the extraction efficiency of such compounds. The glycyrrhizin content in all the extract types was rather low (0.1\% to $1 \%)$ except for extract prepared with water, where the glycyrrhizin content was $-10 \%$ as expected since glycyrrhizin is a polar compound. Interestingly, we observed that ethyl acetate selectively isolated only glabridin with no traces of glycyrrhizin, which is a finding reported for the first time.

Key Words: Licorice, Glabridin, Flavonoids, Glycyrrhizin, Extraction, Solvent polarity

\author{
Çözücü Polaritesinin Özellikle Glabridin Olmak Üzere \\ Glycyrrhiza glabra Köklerindeki Toplam Flavonoitlerin \\ Ekstraksiyonunun Verimine Etkisi
}

$\ddot{O Z Z}$

Farklı organik çözücülerin (etanol, diklorometan, etil asetat ve aseton) Glycyrrhiza glabra köklerinden glabridin ve toplam flavonoit (TF) ekstraksiyon verimliliğine etkileri çalışlmuştır. Glycyrrhiza glabra köklerinden ekstre verimi \% 3 ile \% 6 aralı̆gıda, ekstraksiyon etkinliği etanol> aseton> etil asetat> diklorometan sirası ile bulunmuştur. Diklorometan, ardindan etil asetat, aseton ve etanol ile daha yüksek bir TF ve glabridin ektraksiyon verimi elde edilmiştir, bu da TF ve glabridinin en uygun şekilde ekstraksiyonunda polar olmayan çözücülerin etkili olduğunu göstermektedir. Ayrica flavonoitlerin ektraksiyon verimliliğinin, çözücünün nem absorplama kapasitesinin bu tür bileşiklerin ekstre edilmesinde rol oynadığın yansitan etanol haricinde, geri kazanılan çözücülerin kullanımından büyük ölçüde etkilenmediği de ilk kez gösterilmişstir. Su ile hazırlanan ekstre haricinde tüm ekstre türlerinde glisirizin içeriği düs̈̈̈k olup \% 0,1 ile \% 1 aralı̆̆ındadır, bileşik polar bir bileşik olduğu için su ekstresinde içerik beklendiği gibi -\% 10'dur. İlginç bir şekilde, etil asetatın glisirizin izleri olmadan sadece glabridini seçici olarak izole ettiği ilk kez bildirilen bir bulgu olarak gözlenmiştir.

Anahtar Kelimeler: Meyankökü, Glabridin, Flavonoitler, Glisirizin, Ekstraksiyon, Çözücü polaritesi

" ORCID: 0000-0003-4613-3012, Herbal Division, Sava Healthcare Limited, Research Center, MIDC, Chinchwad, Pune, India.

" ORCID: 0000-0002-0225-910X, Analytical Development Laboratory, Sava Healthcare Limited, Research Center, MIDC, Chinchwad, Pune, India.

"* ORCID: 0000-0002-1981-5651, Analytical Development Laboratory, Sava Healthcare Limited, Research Center, MIDC, Chinchwad, Pune, India.

'... ORCID: 0000-0002-8998-3044, Herbal Division, Sava Healthcare Limited, Research Center, MIDC, Chinchwad, Pune, India.

-..** ORCID: 0000-0003-1664-0443, Ayush Center of Excellence, Interdisciplinary School of Health Sciences, Center of Complementary and Integrative Health, Savitribai Phule Pune University, Pune, India.

....... ORCID: 0000-0002-3037-9168, Dabur Research and Development Center, Ghaziabad, India,

….... ORCID: 0000-0002-1723-8002, Analytical Development Laboratory, Sava Healthcare Limited, Research Center, MIDC, Chinchwad, Pune, India.

........ ORCID: 0000-0001-8049-3703, Sava Healthcare Limited, Research Center, Block D1, Plot No. 17/6, MIDC, Chinchwad, Pune-411019, India 


\section{INTRODUCTION}

Glycyrrhiza glabra Linn, commonly known as 'licorice' and 'sweet wood' belongs to Leguminosae family and is cultivated in Italy, Russia, France, UK, USA, Germany, Spain, China and Northern India (Bhan, 2017).

Licorice is widely used from the ancient medical history of Ayurveda, both as a medicine and as a flavouring agent. Its use as an anti-inflammatory agent during allergenic reactions, as a contraceptive, as a laxative and as an anti-asthmatic agent is reported (Ammosov, 2003). The use of licorice in the treatment of gastric ulcers, hepatitis $\mathrm{C}$ and pulmonary and skin diseases is known and, its use in treating cough because of its demulcent and expectorant property, also exists (Damle, 2014). Licorice extract is also incorporated in medicinal oils to treat rheumatism, haemorrhagic diseases, epilepsy, paralysis etc. (Kaur, 2013).

The chemical constituents of the Glycyrrhiza glabra roots include several bioactive compounds, such as glycyrrhizin ( $\sim 16 \%)$, flavonoids $(1.5 \%)$, coumarin, alkaloids, polysaccharides, sitosterol, amino acids, gums and essential oils (Li, 2012). The hydrophilic fraction of licorice extracts which includes glycyrrhizin and glycyrrhetinic acid, are known to suppresses the replication of numerous viruses such as HIV, HCV, influenza HSV, rotavirus, coxsackievirus, HRSV, HBV (Wang, 2015), while the hydrophobic fraction of licorice extracts containing flavonoids and glabridin (Yokota, 1998) have pharmacological activities of wound-healing (Yip, 2016), anti-microbial (Alwan, 2015), anti-ulcer agent (Alilzadeh-Amin, 2015) etc.

The conventional methods for extraction of glabridin from licorice utilize solvents that need to be free of moisture to have an optimal yield of glabridin, thereby leading to massive amount of solvent waste. Some of the solvents used for glabridin extraction include ethanol (Tian, 2008), acetone (Ao, 2010), ethyl acetate (EA) (Xu, 2009), supercritical fluid $\mathrm{CO}_{2}$ (Cho, 2004), methanol (Bhan, 2017) and imidazoli- um-based ionic liquids (Li, 2012). Also, since glabridin is sensitive to temperature (Ao, 2010), the high energy consumption due to sample extraction time and high extraction temperature affects the final yield of the product. Since the licorice extracts are used in the cosmetic and food industries, having these extracts without residues of toxic solvents would be beneficial. In the light of these issues, an alternate, safe and cost-effective process for extraction of glabridin from licorice assumes critical importance.

The requirement of pure glabridin as a chemical reference standard for quality control studies and identification of Glycyrrhiza glabra roots and for biological/pharmacological investigations (Vishwanathan, 2019), tempted us to reinvestigate the method of extraction of glabridin from licorice so that the processes are cost-effective and reproducible without impacting their quality.

The present study was designed to study the impact of different extraction solvents and its moisture content on the yield of glabridin and total flavonoids (TF) from Glycyrrhiza glabra roots, with particular emphasis also on effects of recovered solvents on the extraction efficiency of TF and glabridin, under similar extraction conditions.

\section{MATERIALS AND METHODS}

\section{Reagents and Chemicals}

The HPLC grade solvents like acetonitrile and methanol, and potassium dihydrogen phosphate were purchased from Rankem (Bangalore, India). Glabridin and glycyrrhizin reference standards were purchased from Natural Remedies Pvt. Ltd, Bangalore, India.

\section{Collection of Glycyrrhiza glabra roots}

Roots of Glycyrrhiza glabra were collected from a commercial source from the Northern part of India. The identity of the roots was confirmed and documented by a taxonomist at Durva Herbal, Tamil Nadu, India. The freshly collected samples of licorice roots were washed, air-dried, and stored at $4^{\circ} \mathrm{C}$, pro- 
tected from light and humidity before analysis.

\section{Preparation of extracts}

$100 \mathrm{~g}$ licorice roots raw material was processed for extraction with four volumes of fresh acetone followed by three volumes of the acetone two times (each extraction for three hours) at $45-50^{\circ} \mathrm{C}$. After extractions, all acetone extractions were pooled and concentrated on a rotary evaporator under vacuum at $45-50^{\circ} \mathrm{C}$ to get a dry powdered acetone extract of Glycyrrhiza glabra. A similar protocol was followed to obtain powdered licorice extracts with EA and ethanol. For extraction with dichloromethane, the extraction temperature was maintained between $30-35^{\circ} \mathrm{C}$, below the boiling point of the dichloromethane solvent, keeping all other extraction parameters constant.

Preparation of licorice extracts using fresh, primary and secondary recovered solvents

After completing the first round of extraction with EA, the used EA was recovered, its volume measured and its moisture content estimated. The primary recovered and distilled EA was later used to extract the glabridin and TF from a fresh aliquot of the Glycyrrhiza glabra roots. Similarly, the volume and the moisture of the secondary recovered EA generated from this extraction run were used for the third extraction of glabridin and TF from a fresh batch of Glycyrrhiza glabra roots powder. A similar protocol was followed for all the other three solvents used, unless mentioned otherwise.

\section{Estimation of moisture content in solvents}

Karl Fisher Titration is a technique for the determination of moisture content. KF Titrando, Metrohm was used, for this purpose. The sensitivity of the method is an accurate determination of water content from 0.001 to $100 \%$.

\section{HPLC conditions}

The glabridin content in the powdered extracts recovered from the process was analyzed using an HPLC system (Shimadzu, 2010CHT) consisting of a quaternary pump with a vacuum degasser, thermostatted column compartment, autosampler, and UV detector.
A reverse-phase column (Inertsil ODS, C18, 3V, $5 \mu \mathrm{m}$, $250 \mathrm{X} 4.6 \mathrm{~mm}$; GL Sciences, Japan) was used with a column temperature of $40{ }^{\circ} \mathrm{C}$. The HPLC mobile phaseSolution A: Potassium dihydrogen phosphate (1.36 g) was dissolved in $1000 \mathrm{~mL}$ of HPLC grade water. The solution was filtered through a $0.45 \mu \mathrm{m}$ membrane filter and degassed in a sonicator for $3 \mathrm{~min}$; Solution B: Acetonitrile (100\%). The mobile phase was run using gradient elution. The gradient program for separation of glabridin and other flavonoids by HPLC was set as (time/\% B) 0/5, 25/40, 40/42, 45/60, 50/60, 55/80, $60 / 80,61 / 5,65 / 5$, that pumped the phases at a rate of $1 \mathrm{~mL} / \mathrm{min}$. The detection wavelength for glabridin was chosen as $280 \mathrm{~nm}$, based on the UV spectra of pure glabridin solution (Shrikant, 2020). The flow rate was kept as $1.0 \mathrm{~mL} /$ minute and injection volume was 20 $\mu \mathrm{L}$. The run time for detection of glabridin by HPLC was $65 \mathrm{~min}$.

The estimation of glycyrrhizinic acid was carried out by HPLC under conditions as follows: Hypersil BDS column ( $3 \mathrm{~V}, 250 \mathrm{~mm} \times 4.6 \mathrm{~mm}, 5 \mu \mathrm{m})$ using an isocratic mobile phase consisting of $2 \%$ formic acid and acetonitrile in the ratio $65: 35 \mathrm{v} / \mathrm{v}$. The flow rate was $1.0 \mathrm{~mL} /$ minute, injection volume was $20 \mu \mathrm{L}$, the column oven temperature was $30^{\circ} \mathrm{C}$ and the run time was 20 minutes. The peak of glycyrrhizinic acid was observed at $254 \mathrm{~nm}$.

\section{Sample preparation}

$50 \mathrm{mg}$ of Glycyrrhiza glabra extract was precisely weighed, and transferred to a $50 \mathrm{~mL}$ volumetric flask. About $30 \mathrm{~mL}$ methanol was added and the contents were sonicated for $20 \mathrm{~min}$. The volume was then made up to $50 \mathrm{~mL}$ with methanol, filtered through a $0.45 \mu \mathrm{m}$ filter and the resulting filtrate was used as a test solution. A stock solution of glabridin standard was prepared at a concentration of $5.0 \mathrm{mg} / \mathrm{mL}$ in absolute methanol. The calibration curves were prepared using solutions of different concentration levels from 10 $550 \mu \mathrm{g} / \mathrm{mL} .5 \mathrm{mg}$ of glycyrrhizin in $50 \mathrm{~mL}$ methanol was used as the reference glycyrrhizin standard solution. 


\section{RESULTS}

\section{HPLC method}

Standard glabridin peak was obtained at the re- tention time of 50.707 min (Figure 1) while the glabridin peak was seen at $50.56 \mathrm{~min}$ with the glabridin extracted using EA (Figure 2).

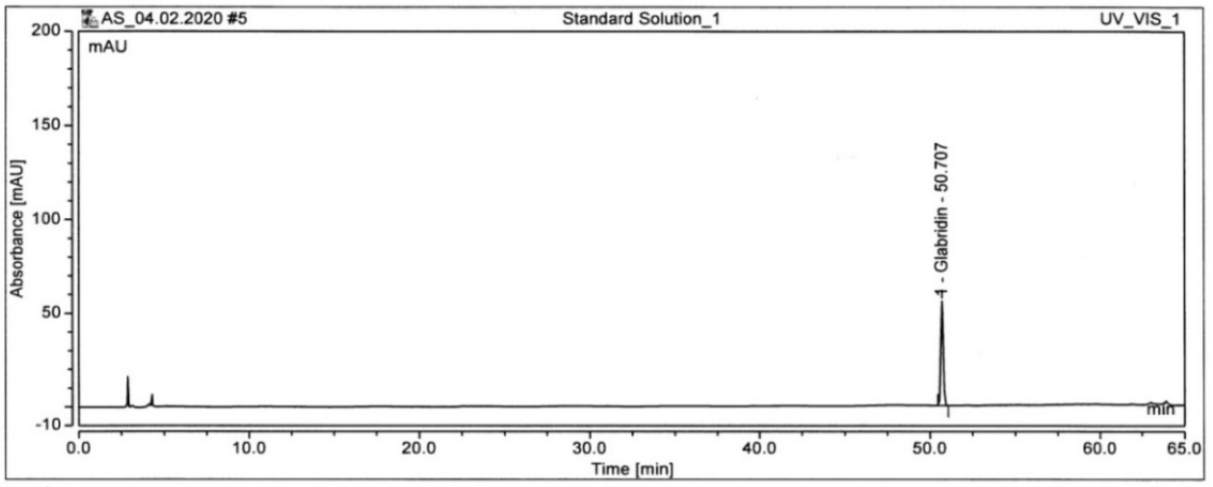

Figure 1. Chromatogram of standard Glabridin. Mobile phase A: Phosphate buffer; Mobile phase B- 100\% acetonitrile, flow rate: $1 \mathrm{~mL} / \mathrm{min}$; detection: $280 \mathrm{~nm}$. The retention time of glabridin was $\sim 51 \mathrm{~min}$.

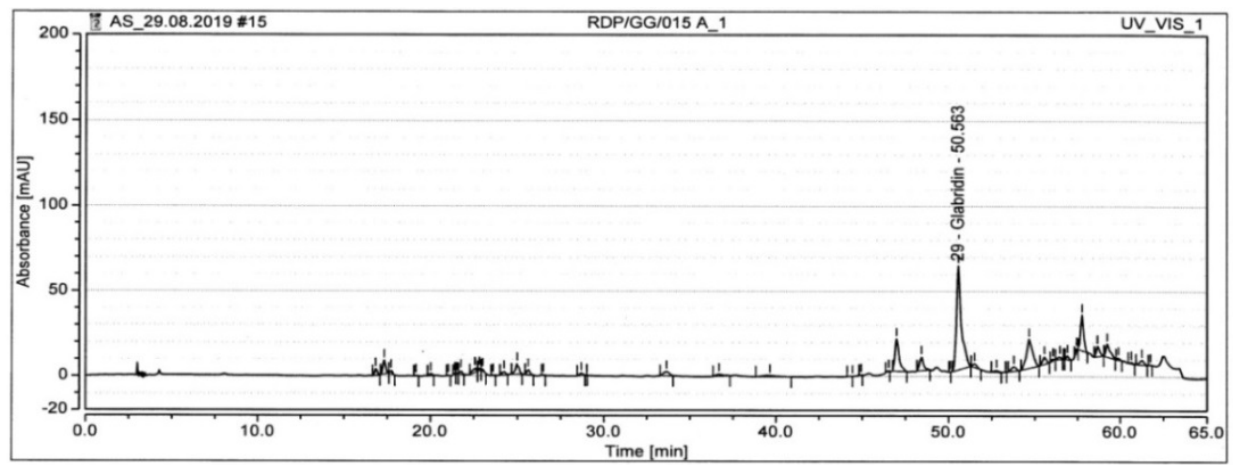

Figure 2. HPLC chromatogram of ethyl acetate extract of licorice roots. Mobile phase A: Phosphate buffer; Mobile phase B- $100 \%$ acetonitrile, flow rate: $1 \mathrm{~mL} / \mathrm{min}$; detection: $280 \mathrm{~nm}$.

Several peaks of the flavonoids eluted at the reten- chromatograms of licorice extracts of acetone, dition times between $5 \mathrm{~min}$ to 63 minutes in the sam- chloromethane and ethanol, respectively, wherein the ple extract and these were integrated for enumeration retention time of glabridin was seen at 51.098, 50.29 of TF content. Figures 3, 4 and 5 represent the HPLC and $50.71 \mathrm{~min}$, respectively.

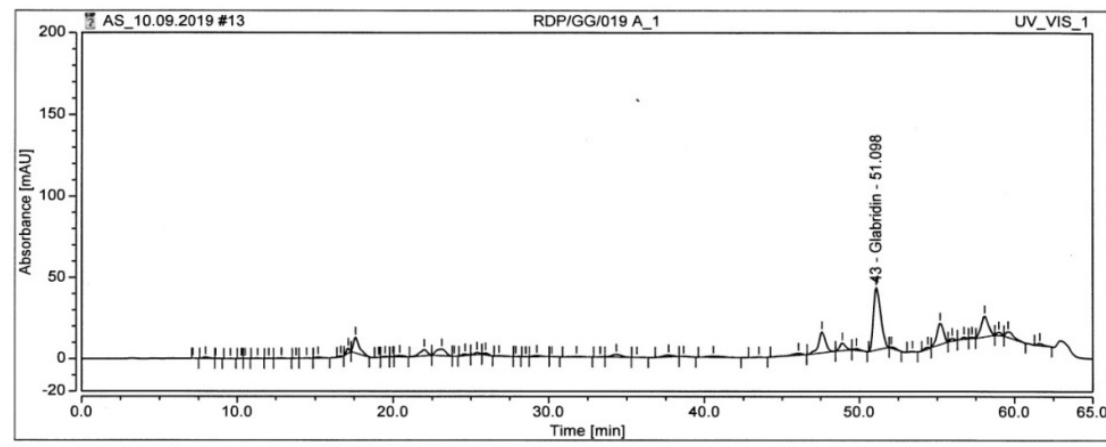

Figure 3. HPLC chromatogram of acetone extract of licorice roots. Mobile phase A: Phosphate buffer; Mobile phase B- $100 \%$ acetonitrile, flow rate: $1 \mathrm{~mL} / \mathrm{min}$; detection: $280 \mathrm{~nm}$. 


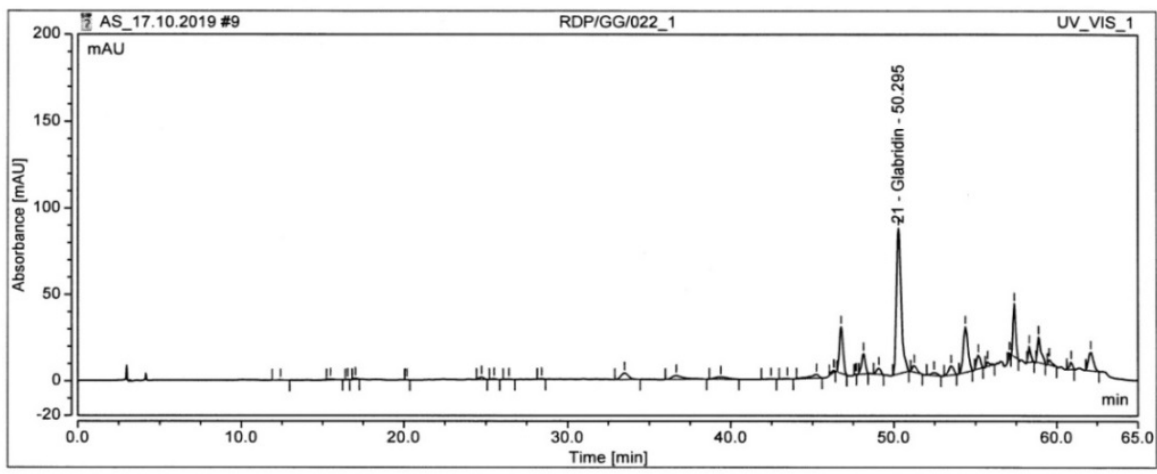

Figure 4. HPLC chromatogram of dichloromethane extract of licorice roots.

Mobile phase A: Phosphate buffer; Mobile phase B- 100\% acetonitrile, flow rate: $1 \mathrm{~mL} / \mathrm{min}$; detection: $280 \mathrm{~nm}$.

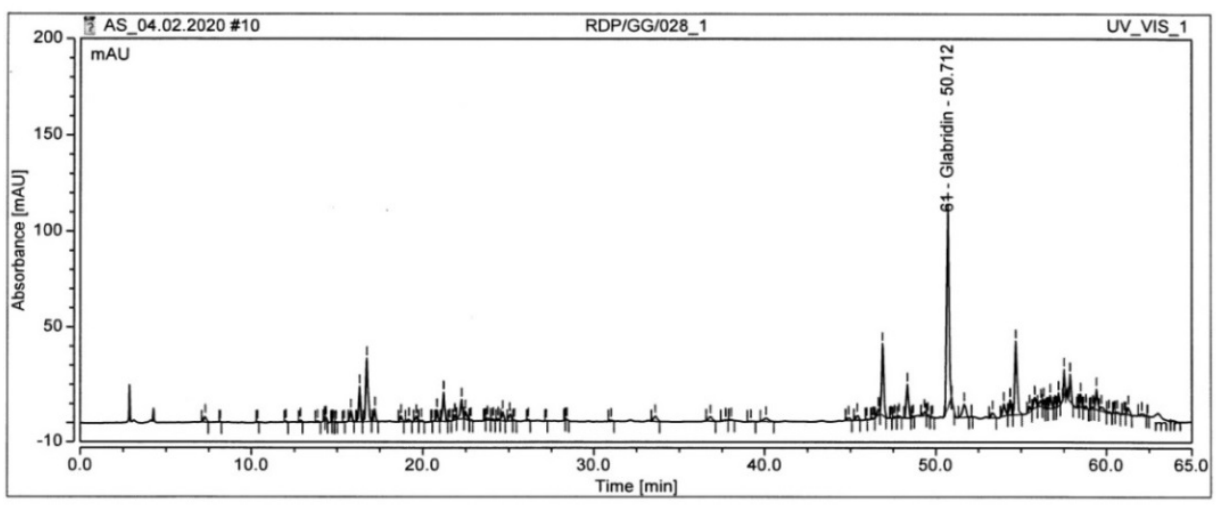

Figure 5. HPLC chromatogram of ethanol extract of licorice roots. Mobile phase A: Phosphate buffer;

Mobile phase B- 100\% acetonitrile, flow rate: $1 \mathrm{~mL} / \mathrm{min}$; detection: $280 \mathrm{~nm}$.

For LOD and LOQ calculations of glycyrrhizinic acid, the established linear equation was $\mathrm{y}=$ $13,783.285 \mathrm{x}-1,242.374$, the $\mathrm{r}^{2}$ (coefficient of determination) was 0.998 , and the calculated LOD and LOQ values were $0.31 \mathrm{mg} / \mathrm{L}$ and $0.95 \mathrm{mg} / \mathrm{L}$, respectively while for glabridin, the established linear equation was $y=52,367.4771 \mathrm{x}-843.7015$, the $\mathrm{r}^{2}$ (coefficient of determination) was 1.000 , and the calculated LOD and LOQ values were $0.13 \mathrm{mg} / \mathrm{L}$ and $0.41 \mathrm{mg} / \mathrm{L}$, respectively. Hence, the quantification range for glycyrrhizinic acid and glabridin by the method described in this paper is from $0.95 \mathrm{mg} / \mathrm{L}$ and $0.41 \mathrm{mg} / \mathrm{L}$ and above respectively.

Glabridin and water content in licorice root extracts using fresh, primary and secondary recovered solvents

The polarity index of acetone, ethanol, EA and dichloromethane is $5.1,5.2,4.4$ and 3.1 respectively and we observed these solvents to have different hygroscopicity values (moisture-absorbing capacity) with acetone topping the list with $5.55 \%$ water content, followed by ethanol (3.4\%), EA $(0.77 \%)$ and dichloromethane $(0.07 \%)$. It is evident from Table 1 that different solvents yielded different extraction yields of licorice roots following the order acetone $>$ ethanol $>$ EA > dichloromethane. The moisture content in the recovered solvents followed the order dichloromethane $<$ EA $<$ ethanol $<$ acetone. The glabridin $\%$ content was maximum with dichloromethane (6.65\%) extract followed by EA (5.59\%), acetone (5.09\%) and ethanol (3.73\%) extracts, with fresh solvents. The glabridin \% and TF content remained constant in all the extracts when recovered solvents were employed for extraction except for ethanol which showed a significant reduction in the yield of glabridin and TF in comparison to the yield achieved with fresh ethanol. 


\section{Glycyrrhizin content in licorice extracts using various solvents}

The RT of the standard glycyrrhizin by the HPLC method employed was found to be nearly $12 \mathrm{~min}$ (Figure 6).

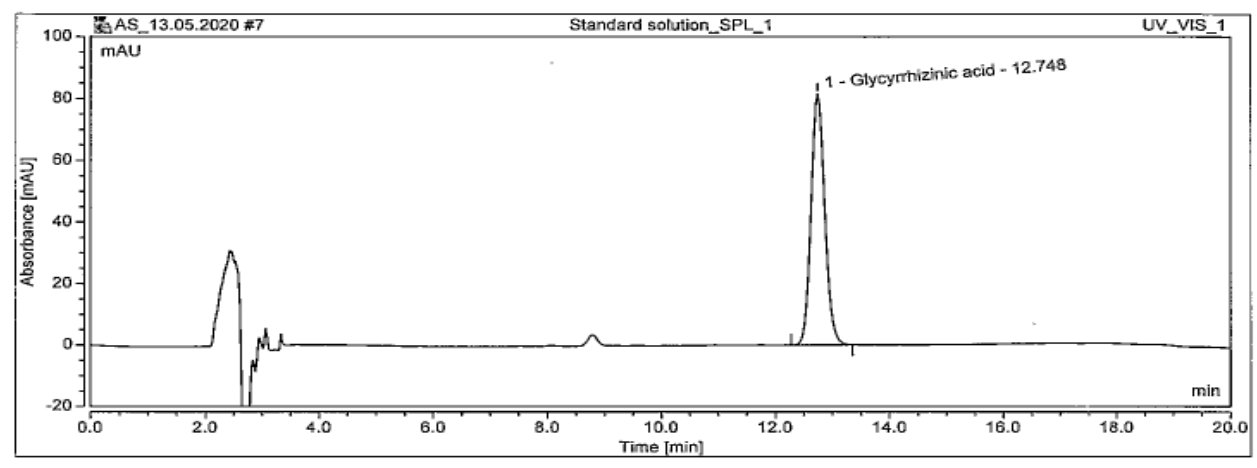

Figure 6. Chromatogram of standard glycyrrhizinic acid. The HPLC was done using an isocratic mobile phase consisting of $2 \%$ formic acid and acetonitrile in the ratio $65: 35 \mathrm{v} / \mathrm{v}$. flow rate: $1 \mathrm{~mL} / \mathrm{min}$; detection: $254 \mathrm{~nm}$.

The retention time of glycyrrhizin was $12.7 \mathrm{~min}$.

Table 1. Effect of extraction solvent and water content of the used solvents on the yield of Glabridin, TF and Glycyrrhizin from licorice roots

\begin{tabular}{|c|c|c|c|c|c|c|}
\hline Lab trial No. & Extraction solvent & $\begin{array}{c}\text { Extract } \\
\text { yield }(\mathrm{g} \%)\end{array}$ & $\begin{array}{l}\text { moisture } \\
\text { content }^{\mathrm{a}} \%\end{array}$ & $\begin{array}{c}\% \text { Glabridin }^{\mathrm{b}} \\
\%\end{array}$ & $\begin{array}{l}\text { Total Flavonoid } \\
\text { content } \%\end{array}$ & Glycyrrhizin ${ }^{c} \%$ \\
\hline RDP/GG/015 & ethyl acetate (fresh) & 5.1 & 0.77 & 5.59 & 17.11 & Not detectable \\
\hline RDP/GG/016 & $\begin{array}{l}\text { ethyl acetate (recovered from RDP/ } \\
\text { GG/015) }\end{array}$ & 5.0 & 1.71 & 5.90 & 18.08 & Not detectable \\
\hline RDP/GG/018 & $\begin{array}{l}\text { ethyl acetate (recovered from RDP/ } \\
\text { GG/016) }\end{array}$ & 5.1 & 3.15 & 5.57 & 17.58 & Not detectable \\
\hline RDP/GG/019 & acetone (fresh) & 5.6 & 5.55 & 5.09 & 16.21 & 0.16 \\
\hline RDP/GG/020 & $\begin{array}{l}\text { acetone (recovered from RDP/ } \\
\text { GG/019) }\end{array}$ & 6.8 & 8.49 & 4.06 & 16.09 & 0.21 \\
\hline RDP/GG/021 & $\begin{array}{l}\text { acetone (recovered from RDP/ } \\
\text { GG/020) } \\
\end{array}$ & 6.3 & 10.6 & 4.92 & 18.08 & 0.26 \\
\hline RDP/GG/022 & dichloromethane (fresh) & 3.5 & 0.07 & 6.65 & 20.04 & 0.12 \\
\hline RDP/GG/023 & $\begin{array}{l}\text { dichloromethane (recovered from } \\
\text { RDP/GG/022) }\end{array}$ & 3.0 & 0.21 & 8.24 & 23.48 & 0.05 \\
\hline RDP/GG/024 & $\begin{array}{l}\text { dichloromethane (recovered from } \\
\text { RDP/GG/023) }\end{array}$ & 3.0 & 0.28 & 7.37 & 22.06 & Not detectable \\
\hline RDP/GG/028 & ethanol (100\%-fresh) & 6.7 & 3.40 & 3.73 & 15.08 & 0.68 \\
\hline RDP/GG/029 & $\begin{array}{l}\text { ethanol } \\
\text { (recovered from RDP/GG/028 }\end{array}$ & 7.1 & 5.74 & 2.04 & 12.13 & 0.94 \\
\hline RDP/GG/030 & $\begin{array}{l}\begin{array}{l}\text { ethanol } \\
\text { (recovered from RDP/GG/029 }\end{array} \\
\end{array}$ & 6.0 & 7.15 & 1.89 & 11.87 & 1.57 \\
\hline RDP/GG/035 & water & 10.0 & $\begin{array}{c}\text { Not } \\
\text { applicable }\end{array}$ & 0.05 & Not applicable & 10.58 \\
\hline
\end{tabular}

As expected, the maximum amount of glycyrrhizinic acid was achieved in the water extract of Glycyrrhiza glabra roots (Table 1, Figure 7, panel b), fol- lowed by ethanolic extract (Table 1, Figure 7, panel a), acetone extract and extract prepared with dichloromethane (Table 1, panel $\mathrm{c}$ and $\mathrm{d}$ respectively). 


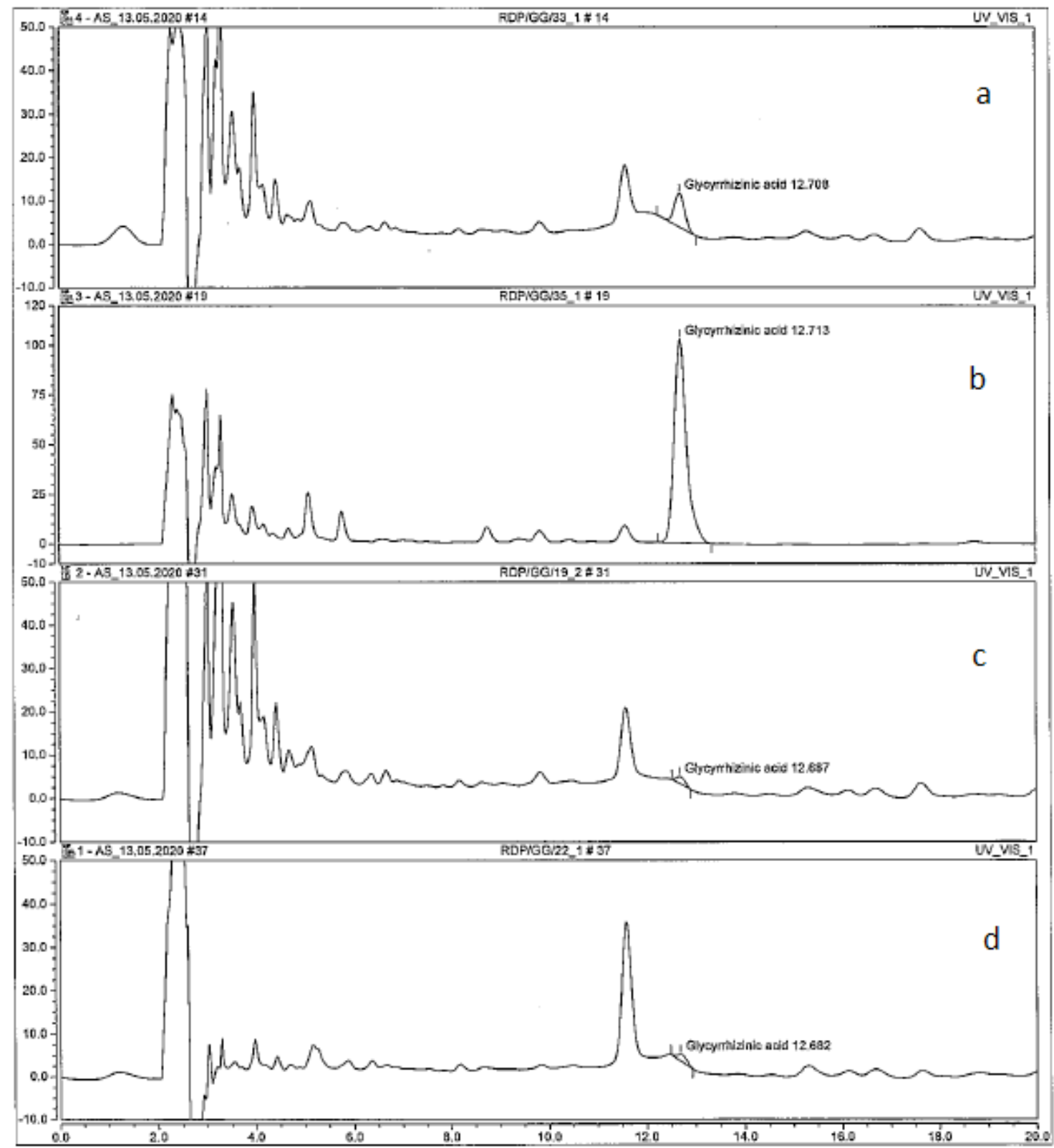

Figure 7. Chromatogram of Glycyrrhiza glabra extracts. Panel a: Ethanolic extract; panel b: water extract; panel c: acetone extract and panel d: dichloromethane extract. The HPLC was done using an isocratic mobile phase consisting of $2 \%$ formic acid and acetonitrile in the ratio $65: 35 \mathrm{v} / \mathrm{v}$. flow rate: $1 \mathrm{~mL} / \mathrm{min}$; detection: $254 \mathrm{~nm}$. The retention time of glycyrrhizin was $12.7 \mathrm{~min}$. 


\section{DISCUSSION}

Medicinal herbs and herbal extracts have been in use for improving human health and building immunity in humans since decades. The first step in the preparation of herbal extracts is the extraction of the bioactive components, its (their) identification and characterization. The most crucial factor affecting the extraction efficiency of such bioactive constituents is the type of extraction solvent employed in the extraction process. In the context of glabridin extraction from licorice, solvents that have been used to date include water, methanol, ethanol, acetonitrile and chloroform (Tian, 2008). Acetone (Ao, 2015), EA (Xu, 2009; Lv, 2010), supercritical carbon dioxide $\left(\mathrm{SC}-\mathrm{CO}_{2}\right)$ with ethanol (Hong, 2019) and 95\% ethanol (Nakagawa, 2002) are some of the solvents used for glabridin extraction.

Since Tian and co-workers reported an optimal extraction of glabridin at 50 and $60^{\circ} \mathrm{C}$ (Tian, 2008), we chose the extraction temperature as $50^{\circ} \mathrm{C}$ in our studies except for dichloromethane, which was operated at $30-35^{\circ} \mathrm{C}$, below its boiling point. The highest yield of glabridin to date is $0.198 \mathrm{wt} \%$ with $95 \%$ ethanol, while it was $0.21 \%$ with acetone. Lv et al. describe the extraction of glabridin using EA with a yield of $0.23 \%$ (Lv, 2010). Our present reporting $\sim 0.29 \%$ yield of glabridin from licorice with EA is highest to date with the time of extraction to a maximum of $6 \mathrm{~h}$ as against $24 \mathrm{~h}$ and $48 \mathrm{~h}$ extraction times reported earlier (Tian, 2008; Hong, 2019). Since the solvent volumes used in this study is close to the volumes of solvents used by other workers, the higher yield of glabridin with EA seen is most probably due to the property of the EA solvent used for extraction.

From our studies, it is also clear that the yield of glabridin from Glycyrrhiza glabra roots was highest with dichloromethane, followed by EA, acetone and ethanol while the total licorice extract output per 100 $\mathrm{g}$ of the raw material (roots of Glycyrrhiza glabra) was maximal in acetone derived extract followed by extract made using ethanol and EA. The extract output was least in extract made using dichloromethane.
The glabridin content per $100 \mathrm{~g}$ of raw material was least with ethanol, followed by dichloromethane, acetone and EA. The glabridin content obtained with dichloromethane was in the range of 7-8\% irrespective of whether the solvent was fresh or recovered, which would make the large-scale production batches of glabridin using dichloromethane cost-effective. The next highest level of glabridin was achieved with EA as the extraction solvent which was consistent (5\%) irrespective of the moisture status of the solvent. Our results of $>7 \%$ extraction yield of glabridin from licorice roots using dichloromethane is the highest report to date. Also, our observation of using dichloromethane to extract glabridin and TF from licorice is reported for the first time. These findings suggest that non-polar solvents like dichloromethane and EA are the ideal solvents for extracting bioactive compounds from Glycyrrhiza glabra roots.

Since EA extract yield was almost double to dichloromethane, we recommend using EA as a solvent for the extraction of glabridin and TF from licorice roots. Our suggestion of EA as a preferred choice of solvent corroborates the observations of Ao and co-workers, who compared the stability of glabridin in seven different organic solvents and demonstrated maximum stability of glabridin in EA followed by acetone (Ao, 2010).

The polarity index of the dichloromethane is lowest followed by EA, acetone and ethanol and this reason could be attributed for the observations of the highest glabridin and TF content in dichloromethane and EA licorice extracts than extracts made with ethanol and acetone.

An HPLC method for simultaneous quantification of three flavonoids and four triterpenoids from licorice is reported (Wang and Yang, 2007). Our HPLC method also separates all flavonoids in a single run. The HPLC method presented, in this article, appears to be better than the described method of Chandrasekararan et al., (2011) since in our gradient HPLC method, all the flavonoid peaks, including the peak of 
glabridin, are base to base resolved efficiently. Also, the proper resolution of all the flavonoid peaks has ensured the chromatographic purity of the individual peaks, thereby enhancing the specificity/selectivity of the developed method. It is noteworthy that the flavonoids, being comparatively less polar, were found mainly in the less polar media like dichloromethane and EA. The extract made using dichloromethane is the optimum solvent of choice as it contains the maximum variety and number of flavonoids and glabridin.

Solvents used in herb extraction need to be volatile and leave no residue when dried. This solvent property will make downstream processing easier, including solvent exchange and bioassay. The used acetone produced during any processing contains varying quantities of water, and when recycled with most conventional recyclers, the distilled acetone has a purity of $96-97.5 \%$. To remove the remaining water and increase the purity of recycled acetone to $\sim 100 \%$, molecular sieves are recommended (Baptista, 2013). All these additional steps would cause extra expenditure and cost to the herbal product. Hence, using a solvent that absorbs the least amount of moisture from plant extracts appears an attractive proposition. Hence, EA appears as an attractive alternative to acetone for such bioactive extractions.

The relative rate of hygroscopicity (the rate of water absorption for a solvent with respect to chloroform) has been reported to be in the order ethanol, 2-propanol, acetonitrile, EA, acetone, methanol, chloroform and the relative rate of evaporation was ether> acetone $>$ chloroform $>$ acetonitrile $>$ methanol $>$ EA $>$ ethanol > 1-propanol> water (Tan, 1982) with the rate of water absorption of acetone and EA being close. Since the yield of glabridin and TF was consistent with EA, it appears tempting to suggest that EA is a better solvent than acetone.

There are several known uses and advantages of EA. EA is used not only in the pharmaceutical indus- try but also in the food and beverage industry (Lee, 2014). EA offers wines a fruity flavour and is used as an artificial flavour in ice creams and cakes. Its use as a solvent for varnishes, lacquers, dry cleaning, stains, for contact lenses, photographic films \& plates, synthetic flavouring, chemical intermediate, perfumes, in the leather processing industry, printing industry, absorbents and adsorbents, adhesives and binding agents, cosmetics, colouring agents, etc. is reported. There are several reports on the use of EA in the extraction of active constituents from medicinal plants where the extraction efficiency is dependent on the polarity of the isolated compound (Altemini, 2017) and our present article substantiates such reports.

Glabridin has many beneficial properties for use in cosmetics where its antioxidant, estrogenic, skin depigmentation, anti-inflammatory, and skin-whitening activities are utilized. In the light of these facts, it would benefit if the content of glabridin from licorice is optimal. Hence, although, dichloromethane showed significantly low moisture-absorption capacity, its low amount of glabridin limits the use in largescale manufacturing.

A survey by the World Health Organization has indicated the use of herbal medicines for primary healthcare since the herbal drugs are safe, natural, relatively accessible, and cheaper than the synthetic drugs (Yewale, 2020). Hence, our present article describing cost-effective methods to manufacture herbal extracts with active antiviral agents is attractive.

\section{ACKNOWLEDGEMENTS}

Thanks are due to Mr. Vinod Jadhav, Chairman, SAVA Healthcare Limited and Mr. Avinaash Mandale, MD, SAVA Healthcare Limited for their constant source of support and encouragement. The authors would also like to thank Mr. Sachin Margaj for formatting the figures of the generated data as per the journal's format. 


\section{CONFLICT OF INTEREST STATEMENT}

All the authors of this article declared no conflict of interest.

\section{AUTHOR CONTRIBUTIONS}

Developing the concept and doing a majority of the literature search (SP), designing the HPLC analyses methodology for estimation of the active constituents (SB and SK). Carrying out some of the HPLC analysis (ZF), carrying out extraction of licorice roots using different solvents together with a few HPLC analyses (SY, SBP and NA). Suggesting the use of dichloromethane as one of the extraction solvents, tested in this study (LS). The manuscript preparation, editing and review (SB and SP).

\section{REFERENCES}

Altemimi, A., Lakhssassi, A., Baharlouei, A., Watson, D.G., Lightfoot, D.A. (2017). Phytochemicals: Extraction, isolation, and identification of bioactive compounds from plant extracts. Plants, 6(4), 1-23. https://doi.org/10.3390/plants6040042

Alwan, A.M., Nesrullah, Z., Faraj, E. (2015). Study the effect of ethanolic extract of Glycyrrhiza glabra on pathogenic bacteria. International Journal of Current Microbiology and Applied Sciences, 4(5), 473-484.

Ammosov, A.S., Litvinenko, V.I. (2003). Triterpenoids of Plants of Glycyrrhiza L. and Meristotropis Fisch. Et Mey Genuses. Pharmaceutical Chemistry Journal, 37, 83-94. https://doi. org/10.1023/A:1024085610712

Ao, M., Shi, Y., Cui, Y., Guo, W., Wang, J., Yu L. (2010). Factors influencing Glabridin stability. Natural Products Communications, 5(12), 1907-1912. https://doi.org/10.1177/1934578X1000501214

Baptista, C.A.C., Zak, P.W., Bittencourt, A.S. (2013). Upgrading recycled acetone to $100 \%$ with molecular sieves. Journal of Plastination, 25(2), 27-32.
Bhan, M., Satija, S., Garg, C., Dureja, H., Garg, M. (2017). A novel approach towards green extraction for Glycyrrhitinic acid by ionic liquid-based microwave-assisted extraction and optimization through response surface methodology. Pharmacognosy Journal, 9(6), 866-872. https://doi. org/10.5530/pj.2017.6.136

Chandrasekaran, C.V., Deepak, H.B., Thiyagarajan, P., Kathiresan, S., Sangli, G.K, Deepak M.,...Agarwal A. (2011). A Dual inhibitory effect of Glycyrrhiza glabra (GutGardTM) on COX and LOX products. Phytomedicine: International Journal of Phytotherapy and Phytopharmacology, 18(4), 278-284. https://doi.org/10.1016/j.phymed.2010.08.001

Cho, Y., Ryu, J. (2004). Supercritical fluid extraction of glabridin from Glycyrrhiza glabra. Proceedings of the 4th International Conference on Separation Science and Technology, 334-337. https://doi. org/10.1142/9789812702623_0066

Damle, M., (2014). Glycyrrhiza glabra (Licorice) - a potent medicinal herb. International Journal of Herbal Medicine, 2(2), 132-136.

Hong, J-H., Jung, I-L., Cho, Y-K., Haam, S., Lee, S-Y., Lim, G.,....Ryu, J-H (2019). Preparation of high-quality glabridin extract from Glycyrrhiza glabra. Biotechnology and Bioprocess Engineering, 24, 666-674. https://doi.org/10.1007/s12257-019-0121-7

Jalilzadeh-Amin, G., Najarnezhad, V., Anassori, E., Mostafavi, M., Keshipour, H. (2015). Antiulcer properties of Glycyrrhiza glabra L. extract on experimental models of gastric ulcer in mice. Iranian Journal of Pharmaceutical Research, 14(4), 1163-1170.

Kaur, R., Kaur, H.P. Dhindsa, A.S. (2013). Glycyrrhiza glabra: a phytopharmacological review. International Journal of Pharmaceutical Sciences and Research, 4(7), 2470-2477. 
Lee, K.J., Song, Y., Oh, Y.C., Cho, W-K., Ma, J.Y. (2014). Isolation and bioactivity analysis of ethyl acetate extract from Acer tegmentosum using in vitro assay and online screening HPLC-ABTS+ System. Journal of Analytical Methods in Chemistry, 2014, 1-15. https://doi.org/10.1155/2014/150509

Li, X., Guo, R., Zhang, X., Li, X. (2012). Extraction of glabridin using imidazolium-based ionic liquids. Separation and Purification Technology, 88, 146150. https://doi.org/10.1016/j.seppur.2011.12.018

Lv, J., Liang, H., Yuan, Q., Xu, Y., Wang, T. (2010). Preparative purification of the major flavonoid glabridin from licorice roots by solid-phase extraction and preparative high- performance liquid chromatography. Separation Science and Technology, 45(8), 1104-1111. https://doi. org/10.1080/01496391003697358

Nakagawa, K., Kishida, H., Arai, N., Nishiyama, T., Mae, T. (2004). Licorice flavonoids suppress abdominal fat accumulation and increase in blood glucose level in obese diabetic KK-A(y) mice. Biological and Pharmaceutical Bulletin, 27(11), 1775-1778.

Shrikant, K., Shital, P., Atul, S., Shrinivas, B., Sriram, P. (2020). RP-HPLC method development and validation for simultaneous estimation of glabridin, glycyrrhizic Acid and total flavonoids in Glycyrrhiza glabra extract: Stability studies of constituents. Global Journal of Pharmaceutical Sciences, 8(3), 555738. DOI: 10.19080/GJPPS.2021.08.555738

Tan, B., Melius, P.P., Ziegler, P. (1982). A simple gas chromatographic method for the study of organic solvents: Moisture analysis, hygroscopicity, and evaporation. Journal of Chromatographic Science, 1982: 20(5), 213- 217. https://doi.org/10.1093/ chromsci/20.5.213
Tian, M., Yan, H. (2008). Extraction of glycyrrhizic acid and glabridin from licorice. International Journal of Molecular Sciences, 9(4): 571-577.

Vishwanathan, V., Pharande, R., Bannalikar, A.K., Gupta, P., Gupta, U., Mukne, A. (2019). Inhalable liposomes of Glycyrrhiza glabra extract for use in tuberculosis: formulation, in-vitro characterization, in vivo lung deposition, and in vivo pharmacodynamic studies, Drug Development and Industrial Pharmacy, 45, 11-20. DOI: 10.1080/03639045.2018.1513025

Wang, L., Yang, R., Yuan, B., Liun, Y., Liu, C. (2015). The antiviral and antimicrobial activities of licorice, a widely used Chinese herb. Acta Pharmaceutica Sinica, B 5(4), 310-315.

Wang, Y-C., Yang, Y-S. (2007). Simultaneous quantification of flavonoids and triterpenoids in licorice using HPLC. Journal of Chromatography B, 850(1-2), 392-399. https://doi.org/10.1016/j. jchromb.2006.12.032

Xu, Y., Yuan, Q., Hou, X., Lin, Y. (2009). Preparative separation of Glabridin from Glycyrrhiza glabra L. Extracts with macroporous resins. Separation Science and Technology, 44(15), 3717-3734. https:// doi.org/10.1080/01496390903182933

Yewale, S., Farash, Z., Kolhe, S., Sakkan, S., Bhope, S., Ambekar, P.,...Padmanabhan, S. (2020). Benefits of Soleris ${ }^{\circledast}$ over the conventional method for enumeration of microbial load in Salacia herbal extract. Polish Journal of Microbiology, 69(4), 453462. https://doi.org/10.33073/pjm-2020-048

Yip, H.Y., Poh, M.S.W., Chia, Y.Y. (2016). The effects of glycyrrhizic acid and glabridin in the regulation of CXCL5 inflammation gene on acceleration of wound healing. Asian Pacific Journal of Tropical Biomedicine, 6(2), 108-113. https://doi. org/10.1016/j.apjtb.2015.10.009 
Yewale, Farash, Kulkarni, Palghadmal, Athawale, Sawant, Bhope, Padmanabhan

Yokota, T., Nishio, H., Kubota, Y., Mizoguch, M. (1998). The inhibitory effect of glabridin from licorice extracts on melanogenesis and inflammation. Pigment Cell Research, 11(6), 955-961. https://doi. org/10.1111/j.1600-0749.1998.tb00494.x 